Jurnal Sewaka Bhakti

Lembaga Penelitian dan Pengabdian Kepada Masyarakat

Universitas Hindu Indonesia Denpasar

Volume 2, Nomor 1 April 2019

ISSN: 2654-2935 (Online)

https://ejournal.unhi.ac.id/index.php/sewakabhakti

pp. 35-51

\title{
MENELUSURI KEBERADAAN JARINGAN IRIGASI SUBAK DI KOTA DENPASAR
}

\author{
Made Novia Indriani, Ida Ayu Putu Sri Mahapatni, I Nyoman Suta Widnyana, I \\ Putu Laintarawan \\ Jurusan Teknik Sipil, Fakultas Teknik, Universitas Hindu Indonesia
}

\begin{abstract}
ABSTRAK
Keberadaan subak di Bali sebagai sistem pengaturan air secara tradisional sudah berusia ribuan tahun. Pada era sekarang yang cenderung berkutat dengan berbagai teknologi terkini mungkin jarang sekali yang mengetahui dan paham mengenai subak atau irigasi tradisional Bali tersebut. Subak merupakan sistem pengelolaan pendistribusian aliran irigasi pertanian khas masyarakat Bali dan terbukti mampu meningkatkan produktivitas pertanian masyarakat Bali. Melalui sistem subak ini para petani mendapatkan jatah air sesuai ketentuan yang diputuskan dalam musyawarah warga. Pengabdian menelusuri keberadaaan jaringan irigasi subak di Kota Denpasar, dilakukan untuk mengetahui keberadaan jaringan irigasi subak serta keberlanjutan pengelolaan jaringan irigasi subak di kota Denpasar. Metode yang digunakan dalam penelitian ini adalah metode deskriptif yang bertujuan untuk membuat deskripsi atau gambaran secara sistematik agar dapat mencapai sasaran yang telah ditetapkan, melalui suatu alur pemikiran yang logis dan sistematis. Adapun teknik pengumpulan data yang dilakukan antara lain melalui telaah referensi maupun pengumpulan data-data sekunder yang diperoleh dari instansi-instansi pemerintahan mengenai informasi subak di kota Denpasar. Sedangkan data primer diperoleh dengan melakukan pengamatan atau observasi di lapangan, survey pengukuran dan juga melalui proses wawancara kepada pihak-pihak yang terlibat langsung mengenai jaringan irigasi subak di wilayah kota Denpasar. Adapun anggota khalayak yang dilibatkan dalam kegiatan pengabdian kepada masyarakat ini antara lain klian subak/pekaseh, serta krama subak atau anggota subak sebagai sumber informasi yang dikumpulkan melalui wawancara dan survey secara langsung di lapangan. Hasil pengumpulan data/ inventarisasi tersebut serta telaah mengenai keberlanjutan pengaturan air irigasi berdasarkan data existing yang sudah terkumpul kemudian diserahkan kepada masyarakat, pengurus subak serta pihak atau instansi terkait pemerintah kota Denpasar. Keberadaan sistem jaringan irigasi subak di kota Denpasar saat ini dengan kondisi baik relatif lebih sedikit dibandingkan dengan kondisi rusak ringan berat, rusak sedang dan rusak ringan. Sehingga untuk keberlanjutan pengelolaan jaringan irigasi subak di kota Denpasar, diperlukan kerjasama dari pihak-pihak yang terkait untuk melakukan kegiatan pencegahan, pemeliharaan serta pengelolaan jaringan irigasi subak dengan baik.
\end{abstract}

Kata Kunci : Jaringan irigasi, Subak, Pengelolaan 


\section{Pendahuluan}

Subak sebagai sistem irigasi, selain merupakan sistem fisik juga merupakan sistem sosial. Sistem fisik diartikan sebagai lingkungan fisik yang berkaitan erat dengan irigasi seperti sumber-sumber air beserta fasilitas irigasi berupa empelan, bendung atau dam, saluran-saluran air, bangunan bendung bagi dan sebagainya, sedangkan sistem sosial adalah organisasi sosial yang mengelola sistem fisik tersebut (Sutawan, 1986). Subak sebagai kumpulan sawah-sawah yang dari saluran yang sama atau dari cabang yang sama dari suatu saluran, mendapat air dan merupakan pengairan.

Keberadaan lembaga tradisional subak ini telah banyak disampaikan oleh para ahli dan masyarakat internasional, salah satu diantaranya (John, S. and Ambler, 1992) menyatakan subak dengan alat keirigasian yang nampaknya sangat sederhana, adalah merupakan salah satu organisasi petani pemakai yang paling canggih di seluruh dunia.Diakui pula oleh badan PBB untuk pendidikan, keilmuan dan budaya (UNESCO) bahwa budaya subak dari bali sebagai bagian dari warisan dunia. Subak dianggap sebagai sistem irigasi yang dapat mempertahankan budaya asli masyarakat Bali. Secara filosofis keberadaan subak di Bali merupakan implementasi dari konsep Tri Hita Karana yang merupakan konsep mengenai hubungan yang harmonis antara manusia dengan Tuhan, manusia dengan alam dan antar manusia.

Sebagai lembaga tradisonal di Bali yang mengatur sistem pengairan di sawah beserta pengelolaan jaringan irigasinya, subak mesti dijaga dan dilestarikan.Maka dalam hal ini pemerintah sebagai pemegang kebijakan selalu berupaya menjaga dan melindungi sekaligus melestarikan keberadaan subak itu sendiri. Untuk itu pemerintah kota Denpasar terus berupaya memberikan perhatian salah satunya dengan program pembinaan penataan kelembagaan dan evaluasi subak sekota denpasar yang dilakukan rutin setiap tahun menyasar subak-subak yang ada di empat kecamatan se-kota Denpasar. Hal ini dilakukan agar eksistensi 
subak dapat dijaga sekaligus mampu memberikan kontribusi terhadap keberadaan lahan-lahan pertanian di kota denpasar demi tercukupinya ketersediaan pangan disamping pelestarian budaya tradisional subak itu sendiri, karena memegang peranan penting dalam pelestarian budaya.

Menurut Surat Keputusan Walikota Denpasar Nomor 188.45/148/HK/2014 tentang penetapan subak-subak se-kota Denpasar tahun 2014, bahwa terdapat 42 subak di kota Denpasar yang tersebar di empat kecamatan yaitu 10 subak di kecamatan Denpasar selatan dengan luas lahan pertanian di tahun 2014 sebesar 845 Ha, sedangkan pada tahun 2015 luas lahan pertanian menjadi 840 Ha. Denpasar barat terdapat 8 subak dengan luas lahan pertanian yang tidak berubah dari tahun 2014 sampai 2015 yaitu sebesar256 Ha. Denpasar timur terdapat 14 subak dimana luas lahan tahun 2014 sebesar 704 Ha, sedangkan di tahun 2015 luas lahan menjadi 701 Ha. Denpasar Utara terdapat 10 subak dengan total luas lahannya dari tahun 2014 sampai tahun 2015 tidak berubah, yaitu sebesar 712 Ha. Maka total luas pertanian keseluruhan di kota Denpasar tahun 2015 yaitu $2.509 \mathrm{Ha}$, sedangkan pada tahun 2014 total luas keseluruhan yaitu sebesar 2.517 Ha. Jadi terdapat 8 Ha lahan pertanian yang telah beralih fungsi dalam kurun waktu selama satu tahun. Lokasi pengabdian menelusuri keberadaan jaringan irigasi subak berada di wilayah administratif kotaDenpasar. Terdapat 42 subak di kota Denpasar yang tersebar di empat kecamatan yaitu 10 subak di kecamatan Denpasar selatan dengan luas lahan pertanian 840 Ha. Denpasar barat terdapat 8 subak dengan luas lahan pertanian 256 Ha.Denpasar timur terdapat 14 subak dimana luas lahan pertanian $701 \mathrm{Ha}$ Denpasar Utara terdapat 10 subak dengan total luas lahannya $712 \mathrm{Ha}$.

\section{Metode Pemecahan Masalah Atau Bahan Dan Metode}

Menelusuri keberadaan sistem jaringan irigasi subak di kota Denpasar merupakan bentuk pengabdian yang dilakukan dengan mengumpulkan data-data di lapangan melalui survey lapangan mengenai jaringan irigasi subak yang berada di seluruh subak yang berada di kota Denpasar. Penelusuran dilakukan dengan 
melakukan wawancara dengan pekaseh serta mengukur secara langsung jaringan irigasi di lapangan. Inventarisasi data yang sudah terkumpul tersebut, kemudian ditelaah kembali sebagai informasi mengenai keberlanjutan pengelolaan jaringan irigasi subak yang berada di kota Denpasar.

Tentunya sebelum melakukan pendataan serta langkah selanjutnya untuk keberlanjutan pengelolaan jarinan irigasi subak, ada beberapa hal yang dipahami terlebih dulu.

Sebagai sebuah sistem irigasi, subak memiliki jaringan irigasi atau fasilitas irigasi seperti bangunan-bangunan yang diperlukan untuk pengaturan air irigasi mulai dari sumber air sampai ke petak-petak sawah petani individual.Fasilitas irigasi tersebut terdiri dari saluran-saluran irigasi beserta bangunan-bangunan irigasi yang merupakan satu kesatuan jaringan irigasi.

Beberapa pengertian dari istilah-istilah berdasarkan PP Nomor 20 tahun 2006 tentang irigasi dan UU Nomor 7 tahun 2004 tentang sumberdaya air (Anonim, 2006) yang kiranya penting untuk dituangkan di sini guna lebih memahami pembahasan mengenai aspek prasarana dan sarana irigasi antara lain adalah sebagai berikut.

1. Air adalah semua air yang terdapat pada, di atas maupun di bawah permukaan tanah.

2. Sumber air adalah tempat/wadah air baik yang terdapat pada, di atas, maupun di bawah permukaan tanah.

3. Irigasi adalah usaha penyediaan dan pengaturan air untuk menunjang pertanian.

4. Jaringan irigasi adalah saluran dan bangunan yang merupakan satu kesatuan dan diperlukan untuk pengaturan air irigasi mulai dari penyediaan, pengambilan, dan penggunaannya.

5. Daerah irigasi (DI) adalah kesatuan wilayah yang mendapat air dari satu jaringan irigasi. 
6. Petak irigasi adalah petak tanah yang memperoleh air irigasi.

7. Petak tersier adalah kumpulan petak irigasi yang merupakan kesatuan dan mendapatkan air irigasi melalui saluran tersier yang sania.

8. Penyediaan air irigasi adalah penentuan banyaknya air yang dapat dipergunakan untuk menunjang pertanian.

9. Pembagian air irigasi adalah penyaluran jatah air dari jaringan utama ke petak tersier.

10. Penggunaan air irigasi adalah pemanfaatan air di tingkat usahatani / lahan pertanian.

11. Pembuangan air irigasi atau drainase adalah pengaliran kelebihan air irigasi yang sudah tidak dipergunakan lagi 1 pada suatu DI (daerah irigasi).

12. Operasi dan pemeliharaan (OP) jaringan irigasi adalah kegiatan pengaturan air dan jaringan yang meliputi penyediaan, pembagian, pemberian, penggunaan, danpembuangannya, termasuk usaha mempertahankan kondisijaringan irigasi agar berfungsi dengan baik.

13. Rehabilitasi jaringan irigasi adalah kegiatan perbaikan jaringan irigasi guna mengembalikan fungsi dan pelayanan irigasi seperti semula.

14. Peningkatan jaringan irigasi adalah kegiatan perbaikan jaringan irigasi guna meningkatkan fungsi dan pelayanan irigasi.

15. Daerah Aliran Sungai (DAS) adalah kawasan yang dibatasi oleh pemisah topografis, yang menampung, menyimpan, dan mengalirkan air ke anak sungai dan sungai utama yang bermuara ke danau atau laut, termasuk di bawah cekungan air tanah.

Berbagai macam saluran irigasi subak adalah sebagai berikut:

1. Saluran utama dari sebuah subak (saluran pembawa primer), kalau tertutup (terowongan) dinamakan aungan dan kalau terbuka disebut telabahgede/telabah aya. Di Bali karena topografinya berbukit-bukit maka petani terpaksa haras membuat terowongan yang tidak jarang mencapai ribuan meter 
panjangnya agar air dapat dialirkan ke sawah-sawah yang lokasinya jauh di bawah. Mungkin jika dibandingkandengan tempat-tempat lain di Indonesia atau bahkan di negara-negara lain, jumlah terowongan yang dibuat secara swadaya oleh para petani di masa lampau dengan teknologi yang sangat sederhana dan yang masih ada sampai sekarang paling banyak terdapat di Bali. Aungan dilengkapi dengan lubang-lubang udara atau tempat-tempat masuk untuk keperluan pemeriksaan dan sekaligus perbaikan apabila ada kerusakan.Lubang-lubang itu dinamakan calung apabila diposisikan horizontal dan bindu jika vertikal terhadap aungan.

2. Telabah pemaron gede (telabah pemaron), adalah saluran pembawa sekunder yang mengairi satu bagian tertentu dari / wilayah persawahan subak.

3. Telabah pemaron cenik (telabah cenik), adalah saluran, pembawa tersier yang mengairi bagian-bagian dari wilayah yang lebih kecil lagi dari bagian wilayah subak yang diairil oleh telabah pemaron gede.

4. Telabah pengalapan, adalah saluran kuarter yang mengairi satu atau lebih blok sawah milik petani perorangan (satu atau lebih sikut/tuluk/cutak sawah). Satu sikut sawah milik petani individual (rata-rata sekitar 35 are) bisa terdiri dari beberapa petak sawah. Terminologi untuk penyebutan nama saluran dan bangunan irigasi yang dipakai oleh petani sering membingungkan karena berbeda antara subak satu dengan subak lainnya di suatu daerah dan antara daerah satu dengan daerah lainnya di Bali. Saluran-saluran yang di bawah tingkat saluran tersier (pemaron cenik) di beberapa tempat sering disebut telabah penyahcah (saluran kuarter) atau telabah pengalapan.Saluran ini selanjutnya di beberapa daerah khususnya di Bali selatan dibedakan menjadi telabah penasan bila dipakai oleh sekitar 10 orangpetani individual (untuk sekitar 10 sikut sawah), dan telabahpanca (untuk mengairi sekitar 5 sikut sawah-sawah milik individual (5 orang anggota subak).Untuk bangunan bagi 
pada telabah penasan dan telabah panca berturut-turut disebut tembuku penasan dan tembuku panca.

5. Talikunda, atau saluran "cacing" adalah saluran yang mendistribusikan air secara adil untuk setiap sikut sawah. Talikunda (ada juga yang menyebut samakunda) kadang- kadang harus dibuat lagi secara khusus misalnya jika ada seseorang pemilik lahan memohon untuk diterima menjadi anggota baru karena ingin bercocok tanam padi sehingga perlu air irigasi.Melalui kesepakatan dari semua anggota subak, biasanya permohonan itu bisa diterima asalkan memenuhi syarat-syarat yang ditetapkan oleh subak secara musyawarah. Apabila lokasi lahan orang tersebut agak terpencil sehingga sulit dibuatkan saluran khusus tanpa mengorbankan lahan sawah milik orang lain yang telah ada maka keadaan ini pun masih bisa di atasi mengingat adanya prinsip paras paros sarpanaya sagilik saguluk salunglung sabayantaka. Mungkin saja pemilik yang akan dikorbankan lahannya itu dengan sukarela mengizinkan tanpa imbalan, namun dewasa ini jika ada kasus seperti ini biasanya orang itu menuntut ganti rugi yang wajar kepada pemilik lahan yang terisolir tersebut.

6. Telabah pengutangan, adalah saluran untuk membuang air yang berlebih (saluran pembuang/drainase). Saluran pembuang untuk subak-subak di Bali sering kali digabung dengan saluran pembawa.Ini disebabkan karena tidak sedikit saluran pembawa yang hanya memanfaatkan alam.Misalnya saja cekungan-cekungan alam seperti jurang kecil (pangkung) langsung saja dimanfaatkan sebagai saluran pembawa sekaligus berfungsi sebagai saluran pembuang.

Banyak saluran pembawa yang dibuat dengan menggali begitu saja punggungpunggung medan sehingga saluran menjadi cukup curam. Hal ini mengakibatkan bahwa lama-kelamaan karena terus-menerus tergerus maka akhirnya dapat berubah menjadi pangkung yang selanjutnya befungsi pula sebagai saluran pembuang. Dengan demikian, saluran-saluran irigasi di Bali , 
berfungsi ganda yakni sebagai saluran pembawa dan pembuang . Manfaat saluran yang berfungsi ganda ini antara lain adalah air yang terbuang dari hulu dapat dimanfaatkan lagi oleh petani di hilir dan penghematan areal karena tak perlu lahan khusus untuk membuat saluran pembuang. Akan tetapi, tidak sedikit pula kelemahannya antara lain dimensi saluran menjadi lebih besar, debit yang besar dan kecepatan tinggi pada titik-titik dengan kemiringan besar mengakibatkan terjadinya gerusan pada dasar saluran; diperlukan bentuk bangunan pembagi air yang khusus, sehingga memerlukan mercu pelimpah mirip dengan empelan/bendung (Norken I.N., I.K.Suputra, 2012).

Menurut Peraturan Pemerintah Nomor 20 Tahun 2006 dan Peraturan Menteri Pekerjaan Umum No.32/PRT/M/2007 menyebutkan bahwa Pengelolaan Jaringan Irigasi adalah kegiatan Operasi dan Pemeliharaan serta rehabilitasi jaringan irigasi di Daerah Irigasi.Operasi dan Pemeliharaan Jaringan Irigasi primer dan sekunder menjadi wewenang dan tanggung jawab pemerintah, pemerintah provinsi, dan pemerintah kabupaten/kota sesuai dengan kewenangannya. Subak dapat berperan serta dalam operasi dan pemeliharaan jaringan irigasi primer dan sekunder sesuai dengan kebutuhan dan kemampuannya.Operasi dan Pemeliharaan jaringan irigasi tersier menjadi hak dan tanggung jawab subak. Dalam hal subak tidak mampu melaksanakan operasi dan pemeliharaan jaringan irigasi yang menjadi hak dantanggung jawabnya pemerintah, pemerintah provinsi, atau pemerintahkabupaten/kota dapat memberikan bantuan dan atau dukungan fasilitas berdasarkanpermintaan subak dengan memperhatikan prinsip kemandirian.

1. Peraturan Pemerintah Republik Indonesia Nomor 20 tahun 2006 khususnya Pada Bab IV pasal 16, 17 dan 18 menjelaskan tentang kewenangan pengelolaan irigasi utama (primer dan sekunder) menjadi wewenang tanggung jawab pemerintah pusat dan pemerintah daerah dengan ketentuan: Daerah Irigasi (DI) dengan luasdiatas 3000 ha menjadi wewenang dan tanggung jawab pemerintah pusat 
2. Daerah Irigasi (DI) antara 1000 ha-3000 ha menjadi kewenangan pemerintah provinsi

3. Daerah Irigasi (DI) lebih kecil dari 1000 ha sepenuhnya menjadi kewenangan dan tanggung jawab pemerintah kabupaten, sedangkan jika berada pada lintas kabupaten maka menjadi tanggung jawab pemerintah provinsi. Jaringan tersier sepenuhnya merupakan tanggung jawab organisasi petani (P3A) dalam hal ini adalah subak.

Pemeliharaan prasarana irigasi atau jaringan irigasi dilakukan dengan tujuan agar kelestariannya tetap terjaga dan kondisinya tetap baik seperti keadaan semula sesuai dengan jangka waktu pelayanan sebagaimana direncanakan.Pemeliharaan harus dilakukan secara teratur dan kontinu untuk mencegah supaya jaringan irigasi tidak cepat rusak dan dapat berfungsi dengan baik selama mungkin.

Beberapa kegiatan penting dalam rangka pemeliharaan jaringan irigasi adalah sebagai berikut.

1. Pencegahan, yaitu sedapat mungkin mencegah terjadinyakerusakan lebih cepat. Termasuk kegiatan pencegahan adalah tidak menanam tanaman dan pohon-pohonan yang-akarnya dapat merusak dinding saluran, tidak menaman rumput gajah pada tanggul saluran, dan Iain-lain.

2. Pemeriksaan, yaitu dilakukan untuk mengetahui kondisi bangunan irigasi utamanya yang senantiasa terendara air. Minimal setahun sekali perlu ada pengeringan jaringan irigasi untuk keperluan pemeriksaan.

3. Pemeliharaan rutin, yaitu kegiatan yang harus dilakukan setiap hari secara kontinu berupa pemeliharaan ringan atau perbaikan-perbaikan kecil yang dapat dilakukan selama eksploitasi berjalan.Termasuk kegiatan ini adalah membersihkan sampah-sampah yang menyumbat saluran irigasi; menutup kebocoran-kebocoran; memotong rumput- rumput yang tumbuh di sekitar saluran, tanggul, dan lain- lainnya; menambal pasangan-pasangan batu yang retak di atas permukaan air; dan kegiatan lain yang relevan. 
4. Pemeliharaan berkala, merupakan kegiatan yang dapat dilakukan secara periodik misalnya setiap satu bulan, dua bulan, atau satu tahun tergantung jenis kegiatan seperti mengecat pintu-pintu air, dan menggali lumpur dan pasir yang tertimbun di saluran irigasi.

5. Pemeliharaan insidentil /perbaikan, merupakan kegiatan yang dilaksanakan apabila jaringan irigasi mengalami kerusakan baik kerusakan ringan maupun berat. Contoh dari kegiatan ini adalah memperbaiki pintu-pintu air, atap rumah $\backslash$ pintu air, dan tanggul yang rusak (perbaikan ringan); memperbaiki kerusakan karena bencana alam; mengganti pintu-pintu air; memperbaiki lantai bendung dan bagian-bagian bangunan beserta saluran yang membutuhkan penutupan air secara total.

6. Pemeliharaan /perbaikan darurat, merupakan kegiatan yang dilakukan jika terjadi kerusakan tiba-tiba atau mendadak akibat bencana alam sehingga jaringan irigasi sama sekali tidak berfungsi. Perbaikan darurat diperlukan agar kerusakan tidak bertambah parah dan eksploitasi tidak terganggu.Contohnya jika saluran irigasi terputus akibat tanah longsor dan erosi maka dibuatkan bangunan darurat dengan bronjong atau tumpukan karung berisi pasir sedemikian rupa sehingga air segera dapat mengalir.

7. Investasi, merupakan kegiatan untuk menambah bangunan atau prasarana fisik seperti bangunan terjun, bangunan ukur debit, dan bangunan irigasi lainnya.

Seperti telah disebutkan di depan bahwa pemeliharaan jaringan irigasi adalah sangat penting untuk mencegah agar kerusakan tidak menjadi semakin parah. Adapun kerusakan jaringan irigasi dapat disebabkan karena berbagai faktor antara lain karena (i) faktor alam seperti bencana banjir, gunung meletus, tanah longsor, erosi, dan sedimentasi; (ii) faktor gangguan binatang seperti ternak yang melintasi saluran dan pematang, tikus, dan ketam yang melobangi dinding saluran air irigasi; (iii) faktor manusia yang sengaja atau tidak sengaja merusak pintu air, 
membobol tanggul, bangunan bagi, mengembalakan ternak pada pematang, dan membuat kolam ikan di saluran; (iv) faktor kesalahan dalam perencanaan dan eksploitasi seperti salah hitung, keliru mempertimbangkan situasi dan kondisi lapangan, pemalsuan campuran semen maupun bahan bangunan, salah ukur, dan kesalahan waktu mengoperasikan pintu.

Diperlukan tindakan preventif dan represif terhadap faktor-faktor yang dapat menyebabkan kerusakan jaringan irigasi guna mencegah terjadinya kerusakan lebih cepat, yaitu sebagai berikut.

1. Langkah-langkah yang bersifat preventif, yaitu tindakan yang diambil sebelum terjadinya kerusakan dan atau untuk mencegah supaya bangunan tidak cepat rusak. Langkah-langkah preventif meliputi penghijauan daerah aliran sungai; proteksi hutan lindung; pembangunan waduk; peningkatan perlindungan jurang; pembuatan tempat permandian ternak termasuk tempat lewat atau penyeberangan hewan, pemasangan tanda-tanda larangan; pemeliharaan tanggul dan tebing saluran agar tetap bersih sehingga tidak menjadisarang tikus; pembuatan pasangan batu kali pada saluranyang banyak ketamnya; perencanaan peningkatan jaringan irigasi secara lebih teliti dengan turut memperhitungkan kondisi medan berdasarkan penelitian; penggunaan bahan-bahan bangunan dan campuran sesuai bestek; pembuatan manual atau pedoman eksploitasi jaringan irigasi; peningkatan pengetahuan dan keterampilan petugas dalam bidang OP yang memadai.

2. Langkah-langkah yang bersifat represif, yaitu kegiatan atau tindakan-tindakan yang ditempuh setelah kerusakan terjadi atau merupakan kegiatan langsung guna mencegah terjadinya kerusakan yang lebih parah. Ini meliputi kegiatankegiatan berikut: rehabilitasi prasarana irigasi yang rusak akibat bencana alam; pemeriksaan dan pemeliharaan secara rutin / berkala; kegiatan perbaikan; perlindungan terhadap gangguan ternak dan pcmberian sanksi kepada pemilik / ternak yang mengganggu berupa pembebanan biaya perbaikan; pembasmian 
tikus-tikus serta sarangnya; pengeringan saluran dan penangkapan ketamketam yang ada; perbaikan pasangan-pasangan batu yang rusak; penutupan lobang-lobang pada dinding saluran; pemberiari tegoran dan sanksi kepada orang-orang yang merusakl fasilitas irigasi; perbaikan rencana peningkatan jaringan irigasi sesuai kebutuhan medan; dan kegiatan lain yang relevan.

Hasil dokumentasi menelusuri keberadaan subak di Kota Denpasar, sebagai berikut :

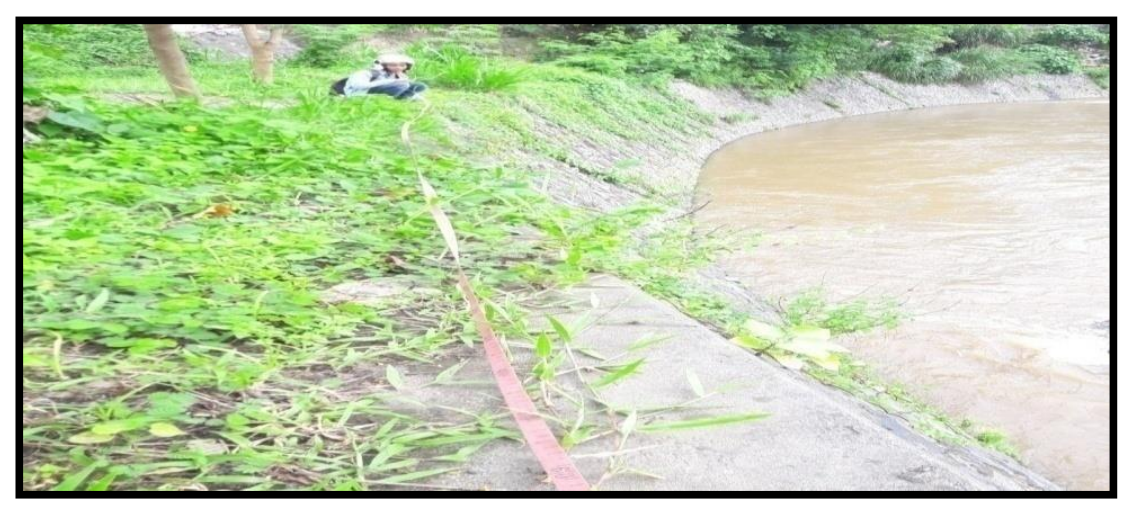

Pengukuran panjang sungai dentim

Sumber aliran air pada sungai ini berasal dari Sungai Oongan, sungai ini mengaliri beberapa subak di Denpasar Timur yaitu Subak Buaji, Subak Delodsema dan Subak Kedaton. Sungai ini mengalir ke Denpasar selatan dan mengaliri beberapa subak disana yaitu Subak Sanur, Subak Intaran Barat, Subak Intaran Timur, Subak Renon, Subak Panjer dan Subak Sidakarya.

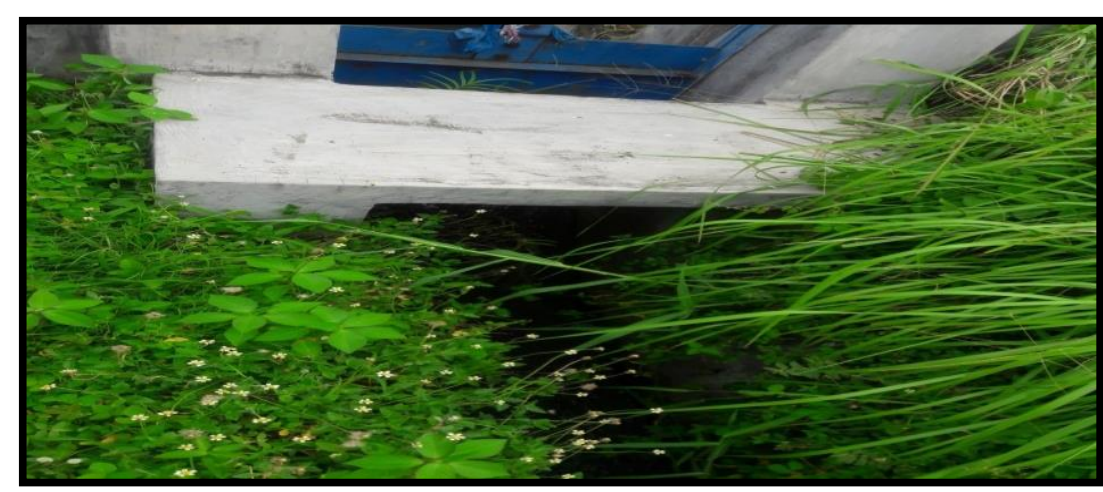

Bangunan bagi dentim 
Jurnal Sewaka Bhakti

Lembaga Penelitian dan Pengabdian Kepada Masyarakat

Universitas Hindu Indonesia Denpasar

Volume 2, Nomor 1 April 2019

ISSN: 2654-2935 (Online)

https://ejournal.unhi.ac.id/index.php/sewakabhakti

pp. 35-51

Bangunan ini berada di Subak Anggabaya, bangunan ini membagi saluran irigasi yg ada di Subak Anggabaya, dengan kondisi bangunan masih bagus.

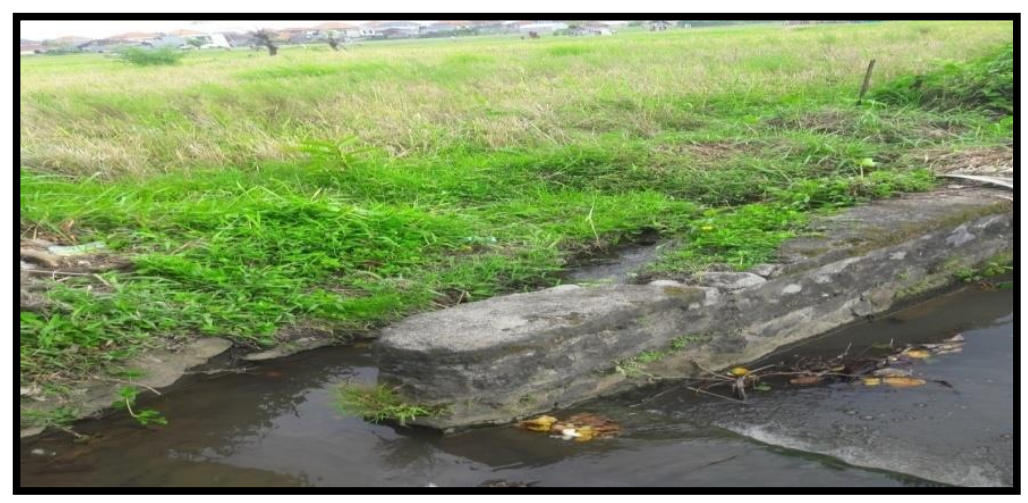

Bangunan sadap dentim

Bangunan ini mengalirkan air dari saluran sekunder ke sawah di Subak

Anggabaya, kondisi bangunan ini rusak pada dasar saluran yang

mengakibatkan aliran air tidak lancar ketika air yg mengalir sedikit karena dasar saluran yang mengalami kerusakan.

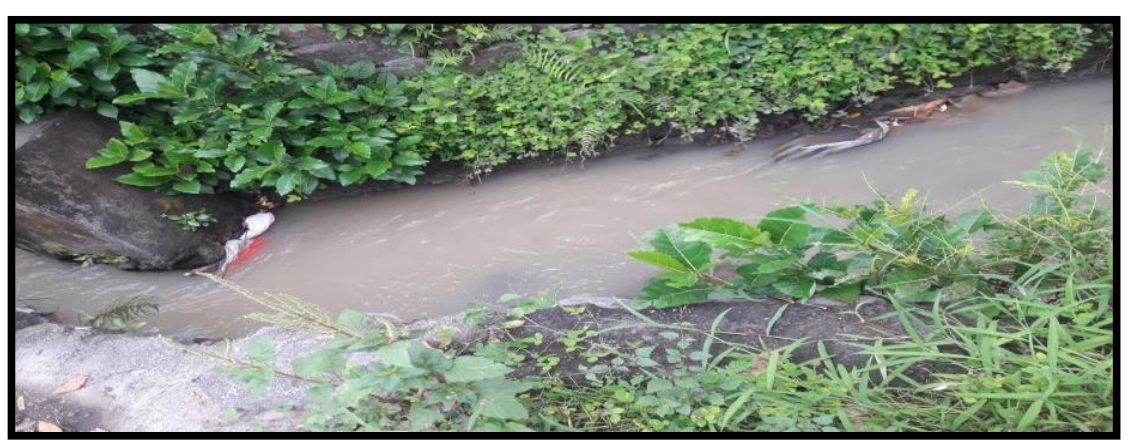

Saluran primer dentim

Saluran ini mengalirkan air ke saluran-saluran sekunder di Subak Anggabaya, keadaan saluran ini seperti terlihat pada gambar, dimana pada dasar saluran masih belum di beton, hanya pada satu sisi saja yg di sender beton agar tanah tidak longsor. 
Jurnal Sewaka Bhakti

Lembaga Penelitian dan Pengabdian Kepada Masyarakat

Universitas Hindu Indonesia Denpasar

Volume 2, Nomor 1 April 2019

ISSN: 2654-2935 (Online)

https://ejournal.unhi.ac.id/index.php/sewakabhakti

pp. 35-51

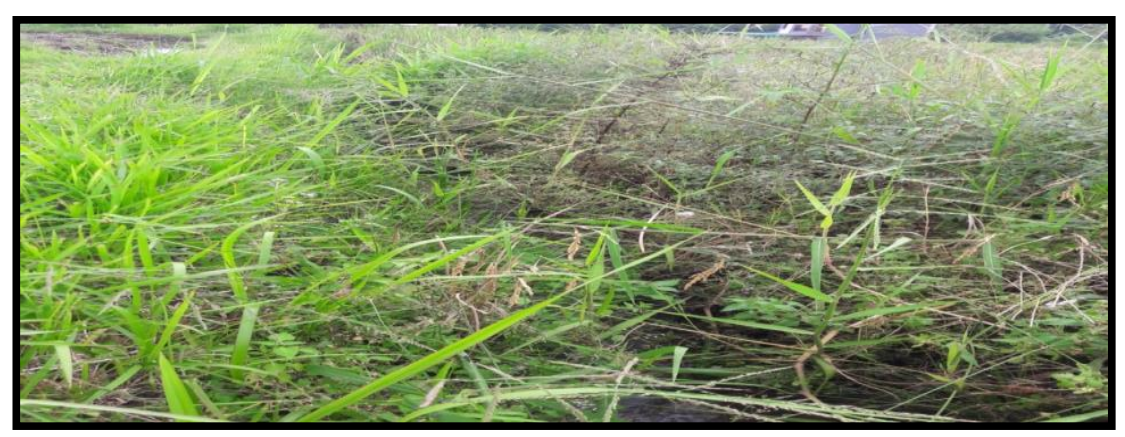

Saluran tersier pakel 1 denut

Keadaan saluran yang masih berupa tanah yg belum di beton, sehingga air langsung mengalir ke petak sawah.

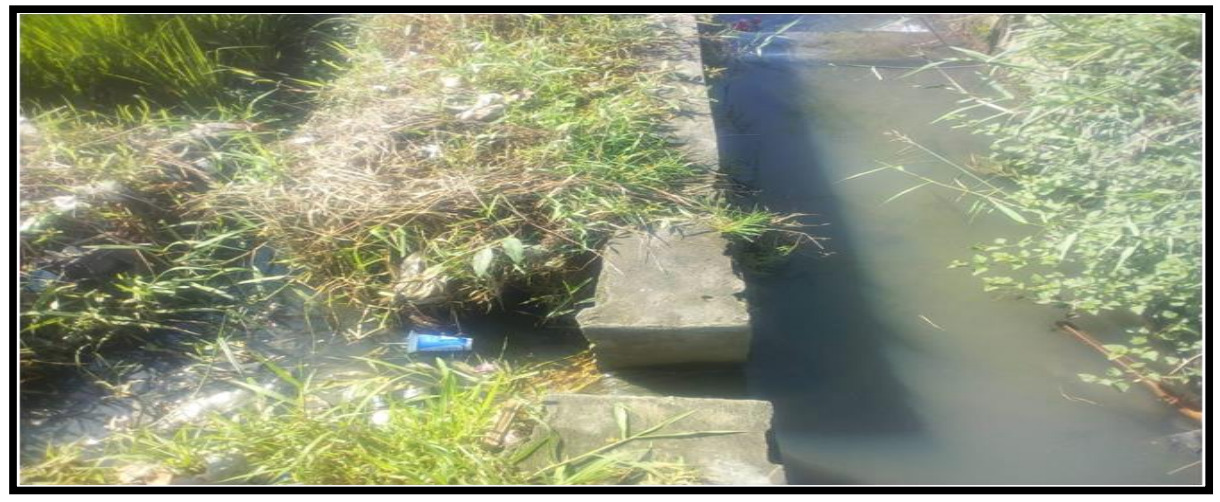

Bangunan sadap Subak Pagutan denbar

Bangunan ini berfungsi untuk membawa aliran air dari saluran sekunder langsung mengairi sawah pada subak pagutan Denpasar barat.Keadaan bangunan ini cukup baik berfungsi sebagaimana mestinya

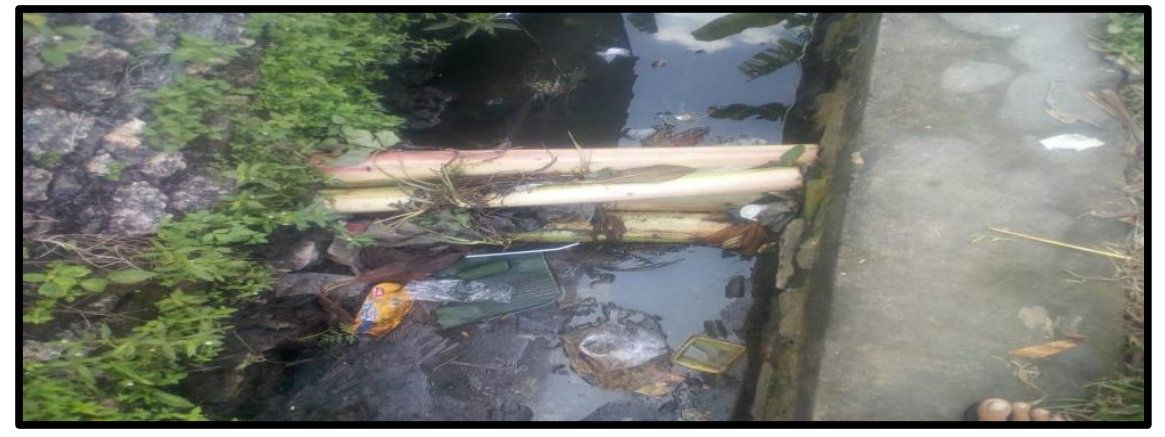

Saluran sekunder Subak Kepaon densel 
Saluran ini berfungsi mengalirkan air dari saluran primer pada Subak Kepaon ke saluran tersier yang kemudian di alirkan ke sawah. Keadaan pada saluran ini mengalami kerusakan pada beton dasar saluran dan banyaknya sampah yang menyebabkan air tergenang.

\section{Hasil Dan Pembahasan}

1. Keberadaan sistem jaringan irigasi subak di kota Denpasar saat ini :

a. Denpasar Utara, subak yang tidak aktif yaitu Peraupan Barat dan Peraupan Timur, sisanya masih produktif. Kondisi baik bila keadaan bangunan pada saluran masih sempurna dan berfungsi dengan baik. Rusak ringan bila beberapa bagian bangunan mengalami retakan. Rusak Sedang beberapa bagian saluran jebol. Rusak Berat beberapa bagian jebol dan beton pada dasar saluran hanyut.

Kondisi Subak Denpasar Utara dengan luas 1.388 ha, total panjang saluran $57.100 \mathrm{~m}$, dengan bangunan bagi 35 buah dan 7 buah bangunan sadap antara lain :

- $\quad$ Kondisi baik $=13.270 \mathrm{~m}$

- $\quad$ Kondisi rusak ringan $=15.980 \mathrm{~m}$

- $\quad$ Kondisi rusak sedang $=5.750 \mathrm{~m}$

- $\quad$ Kondisi rusak berat $=22.100 \mathrm{~m}$

b. Kondisi Subak Denpasar Timur dengan luas total 653 ha. total panjang saluran $27.150 \mathrm{~m}$, dengan bangunan bagi 17 buah dan bangunan sadap 10 buah antara lain :

- $\quad$ Kondisi baik $=10.525 \mathrm{~m}$

- $\quad$ Kondisi rusak ringan $=2.550 \mathrm{~m}$

- $\quad$ Kondisi rusak sedang $=5.025 \mathrm{~m}$

- $\quad$ Kondisi rusak berat $=9.050 \mathrm{~m}$

c. Kondisi Subak Denpasar Barat dengan luas 248 ha, total panjang saluran $23.600 \mathrm{~m}$, dengan bangunan bagi 3 buah antara lain : 
- $\quad$ Kondisi baik $=5.890 \mathrm{~m}$

- $\quad$ Kondisi rusak ringan $=4.100 \mathrm{~m}$

- $\quad$ Kondisi rusak sedang $=4.500 \mathrm{~m}$

- $\quad$ Kondisi rusak berat $=9.110$

d. Denpasar Selatan, subak yang tidak aktif yaitu Subak Sesetan, tiga tahun yang lalu, masih sisa 200 meter, tetapi sekarang sudah tidak ada lagi, sedangkan subak yang lain di wilayah Denpasar Selatan masih produktif, Kondisi Subak Denpasar Selatan dengan luas 804 ha, total panjang saluran $24.550 \mathrm{~m}$, dengan bangunan bagi 13 buah dan 23 buah bangunan sadap antara lain :

- $\quad$ Kondisi baik $=11.500 \mathrm{~m}$

- $\quad$ Kondisi rusak ringan $=1.100 \mathrm{~m}$

- $\quad$ Kondisi rusak sedang $=0 \mathrm{~m}$

- $\quad$ Kondisi rusak berat $=11.950 \mathrm{~m}$

\section{Penutup}

Untuk keberlanjutan pengelolaan jaringan irigasi subak di kota Denpasar, mengingat kondisi kerusakan yang terjadi, diperlukan komunikasi, koordinasi, dan kerjasama dari pihak-pihak yang terkait untuk melakukan kegiatan pencegahan, pemeliharaan serta pengelolaan saluran jaringan irigasi subak di Kota Denpasar dengan baik dan berkelanjutan, dengan demikian diharapkan subak sebagai warisan budaya lokal yang mendunia masih tetap terjaga di kota Denpasar dan pengabdian ini juga menjadi acuan untuk keberlangsungan dan keberlanjutan subak-subak yang ada di seluruh Bali. 
https://ejournal.unhi.ac.id/index.php/sewakabhakti

\section{Daftar Pustaka}

Anonim (2006) 'PP Nomor 20 tahun 2006 tentang irigasi dan UU Nomor 7 tahun 2004 tentang sumberdaya air'. Indonesia.

John, S. and Ambler (1992) Dinamika Irigasi Petani: Kerangka dan PrinsipPrinsip Kelembagaan. Irigasi di. Jakarta: Kelembagaan LP3ES.

Norken I.N., I.K.Suputra, dan I. G. N. K. A. (2012) Partisipasi Anggota Subak Dalam Pemeliharaan Kabupaten, Jaringan Irigasi (Studi Kasus Pada Subak Pecelengan Pedukuan Di Kecamatan Mendoyo Jembrana). Denpasar.

Sutawan, N. (1986) 'Struktur dan Fungsi Subak', Makalah Seminar Peranan Berbagai Program Pembangunan dalam Melestarikan Subak. Bali: Universitas Udayana. 